\title{
Long range transport and fate of a stratospheric volcanic cloud from Soufrière Hills volcano, Montserrat
}

\author{
A. J. Prata ${ }^{1}$, S. A. Carn $^{2}$, A. Stohl ${ }^{1}$, and J. Kerkmann ${ }^{3}$ \\ ${ }^{1}$ Norwegian Institute for Air Research (NILU), P.O. Box 100, 2027 Kjeller, Norway \\ ${ }^{2}$ Joint Center for Earth Systems Technology (JCET), University of Maryland Baltimore County, Baltimore, MD 21250, USA \\ ${ }^{3}$ European Organisation for the Exploitation of Meteorological Satellites (EUMETSAT), Am Kavalleriesand 31, 64295 \\ Darmstadt, Germany
}

Received: 31 January 2007 - Published in Atmos. Chem. Phys. Discuss.: 3 April 2007

Revised: 16 July 2007 - Accepted: 24 September 2007 - Published: 4 October 2007

\begin{abstract}
Volcanic eruptions emit gases, ash particles and hydrometeors into the atmosphere, occasionally reaching heights of $20 \mathrm{~km}$ or more, to reside in the stratospheric overworld where they affect the radiative balance of the atmosphere and the Earth's climate. Here we use satellite measurements and a Lagrangian particle dispersion model to determine the mass loadings, vertical penetration, horizontal extent, dispersion and transport of volcanic gases and particles in the stratosphere from the volcanic cloud emitted during the 20 May 2006 eruption of Soufrière Hills volcano, Montserrat, West Indies. Infrared, ultraviolet and microwave radiation measurements from two polar orbiters are used to quantify the gases and particles, and track the movement of the cloud for 23 days, over a distance of $\sim 18000$ $\mathrm{km}$. Approximately, $0.1 \pm 0.01 \mathrm{Tg}(\mathrm{S})$ was injected into the stratosphere in the form of $\mathrm{SO}_{2}$ : the largest single sulphur input to the stratosphere in 2006. Microwave Limb Sounder measurements indicate an enhanced mass of $\mathrm{HCl}$ of $\sim 0.003$ $0.01 \mathrm{Tg}$. Geosynchronous satellite data reveal the rapid nature of the stratospheric injection and indicate that the eruption cloud contained $\sim 2 \mathrm{Tg}$ of ice, with very little ash reaching the stratosphere. These new satellite measurements of volcanic gases and particles can be used to test the sensitivity of climate to volcanic forcing and assess the impact of stratospheric sulphates on climate cooling.
\end{abstract}

\section{Introduction}

The current low sulphate content of the stratosphere is largely due to the recent absence of significant stratospheric injections of volcanic $\mathrm{SO}_{2}$. The last major injections occurred during the eruptions of El Chichón, March/April $1982(\sim 4 \mathrm{Tg} S)$, the eruptions of Pinatubo from June 12$15,1991(\sim 10 \mathrm{Tg} \mathrm{S})$, followed soon after by the eruption of

Correspondence to: A. J. Prata

(fred.prata@nilu.no)
Cerro Hudson, in August 1991 ( 2 Tg S). Trend estimates using mostly longterm balloon measurements (Deshler et al., 2006), suggest that there is no detectable change in the background stratospheric aerosol. Recently it has been suggested that injecting sulphur into the stratosphere could be employed as a strategy to reduce global warming due to increasing $\mathrm{CO}_{2}$ levels (Crutzen, 2006; Wigley, 2006). Such potentially dangerous tampering with the climate system requires very careful consideration, involving modelling the effects on the climate system. Volcanic eruptions that inject $S$ into the stratosphere provide a natural analogue for assessing the impact on the climate system (Robock, 2004; Wigley, 2006). While there is a crucial difference to the climate response from low-level episodic $\mathrm{SO}_{2}$ injections, highlevel (stratospheric) injections and continuous injections of the kind suggested in the geo-engineering approach, all require accurate observations of the $\mathrm{SO}_{2}$ loading in order to model the climate's response. Accurate measurements of the amount, transport and chemical fate of stratospheric volcanogenic $\mathrm{SO}_{2}$ are therefore of some value, and satellite measurements are well suited to this task.

Stratospheric sulphate causes surface cooling and stratospheric warming (Robock, 2000). Crutzen (2006) estimates that the average annual injection required to effect a cooling of $1.4 \mathrm{Wm}^{-2}$ is about $1-2 \mathrm{Tg}(\mathrm{S})$ per year, but this assumes average stratospheric sulphur loading from volcanoes. On average, volcanoes are believed to inject $0.5-1.5 \mathrm{Tg}(\mathrm{S})$ per year into the stratosphere (Halmer et al., 2002); with a large portion of this due to fewer than 2-3 events each year, but this is highly variable. At the present time, the annual injection of S into the stratosphere from volcanoes is very poorly known. Measurements of total $\mathrm{S}$ injected into the atmosphere from volcanoes are based on low accuracy, largely intermittent and incomplete ground-based correlation spectrometer (COSPEC) and differential optical absorption spectroscopy measurements (McGonigle et al., 2002), while since 1979 the NASA Total Ozone Mapping Spectrometer - TOMS has

Published by Copernicus Publications on behalf of the European Geosciences Union. 
provided (also with limited accuracy) global estimates of volcanic $\mathrm{SO}_{2}$ emissions to the upper troposphere and stratosphere (Krueger et al., 1995), leading to a best estimate of 7.5-10.5 $\mathrm{Tg}(\mathrm{S})$ per year for volcanic sulphur (Halmer et al., 2002).

Our knowledge of the stratospheric sulphate content has been greatly improved through the use of satellite-borne instruments capable of providing global data on a continuous basis (e.g. TOMS), and these have been used to determine volcanic $\mathrm{SO}_{2}$ burdens (Bluth et al., 1993). While there is no single satellite instrument dedicated to this task, several instruments with alternate primary objectives can be exploited to determine $\mathrm{SO}_{2}$ concentrations. The main objective of this paper is to report satellite observations of stratospheric loadings of $\mathrm{SO}_{2}$ due to the May 2006 eruption of Soufrière Hills volcano. We are also able to derive loadings of ice and $\mathrm{HCl}$ in the stratospheric cloud from rapid-scan geosynchronous infrared satellite measurements and from passive microwave satellite measurements, respectively. In the following sections we describe the satellite data used, provide some background on the Soufrière Hills volcanic eruption, describe the methodologies used to derive $\mathrm{SO}_{2}$ from the satellite measurements, and discuss the transport of the $\mathrm{SO}_{2}$ cloud and compare this to results from a particle dispersion model. The paper suggests ways to utilise $\mathrm{SO}_{2}$ measurements in climate models and stresses the need for more accurate global estimates of stratospheric $\mathrm{S}$.

\section{Satellite data}

\section{$2.1 \quad$ AIRS}

The Atmospheric Infrared Sounder - AIRS on board the polar-orbiting EOS-Aqua platform is an echelle spectrometer designed to measure atmospheric profiles of temperature, moisture and trace gases for climate and weather prediction applications. AIRS covers the infrared spectrum from $\sim 3.3 \mu \mathrm{m}$ to $\sim 16.7 \mu \mathrm{m}$ which includes $\mathrm{SO}_{2}$ absorption features at 4, 7.3, and $8.6 \mu \mathrm{m}$. Carn et al. (2005) and Prata and Bernardo (2007) have shown that AIRS measurements can be used to derive $\mathrm{SO}_{2}$ column abundances. The data are provided via anonymous FTP from the data processing centre at NASA Goddard. Level 1b v4.0.0 calibrated and georeferenced radiances on an image grid comprising 2378 channels by 90 pixels by 135 lines are used. The radiometric accuracy is better than $0.5 \mathrm{~K}$, but this does vary with channel. Further information about the AIRS instrument and data processing methods can be found at http://airs.jpl.nasa.gov.

\subsection{MSG-SEVIRI}

The Meteosat Second Generation (MSG), Spin Enhanced Visible and InfraRed Imager (SEVIRI) provides data at 15 min intervals in 8 discrete spectral bands over a $70^{\circ}$ field of view centred at the Greenwich Meridian and the equator. This sensor is specifically designed to provide data for the European weather services and is an operational satellite. SEVIRI has channels at 4, 7.3 and $8.6 \mu \mathrm{m}$ which, like AIRS, cover $\mathrm{SO}_{2}$ absorption features, albeit at much reduced spectral resolution. The rapid scan nature of SEVIRI, coupled with multispectral infrared measurements permit estimates of both $\mathrm{SO}_{2}$ and ice mass loadings and allow us to follow the development of the stratospheric injection over the first $36 \mathrm{~h}$ or so after the eruption.

\subsection{MLS}

The Microwave Limb Sounder - MLS measures microwave emission from the atmospheric limb to determine concentration profiles and total columns of a variety of chemical species including $\mathrm{HCl}$ and $\mathrm{SO}_{2}$ (Waters et al., 2006). At the present time only $\mathrm{HCl}$ profiles were available and we make use of version 1.52 level 2 geolocated geophysical parameter data from the NASA Goddard Space Flight Center Earth Sciences (GES) Data and Information Services Center (DISC). Further details of the data can be found in documents available from the GES-DISC website (http://mls.jpl. nasa.gov/data/overview.php).

\subsection{OMI and CALIOP}

Details of the $\mathrm{SO}_{2}$ ultra-violet measurements from the Ozone Monitoring Instrument (OMI) and backscatter from the Cloud-Aerosol Lidar and Infrared Pathfinder Satellite Observations (CALIPSO) utilising the Cloud-Aerosol Lidar with Orthogonal Polarization (CALIOP) for this volcanic gas cloud, with a focus on the volcanology are described by Carn et al. (2007). The focus here is on the use of infrared measurements and a dispersion model to study the gas and particle constituents and subsequent stratospheric transport of the cloud. The combined use of these satellite instruments for studying the atmospheric chemistry of volcanic emissions is new, and allows much greater confidence in assessing the dynamics and structure of volcanic gas clouds. The infrared instruments provide column $\mathrm{SO}_{2}$ measurements and ice loadings, while the MLS retrieves $\mathrm{HCl}$ profiles.

\section{Soufrière Hills eruption, 20 May 2006}

Soufrière Hills volcano, on the island of Montserrat $\left(16.7^{\circ} \mathrm{N}\right.$, $\left.62.2^{\circ} \mathrm{W}, 915 \mathrm{~m}\right)$ has been in a state of eruption since 18 July 1995. On the morning of 20 May 2006 after several months of lava dome building, the eastern flank of the volcano suffered a major collapse involving an estimated volume of $90 \times 10^{6} \mathrm{~m}^{3}$ of lava, much of it entering the ocean. During or immediately following this event, a highly buoyant eruption column of ash and gases rose to heights of at least $17 \mathrm{~km}$, and as we will show, the gases penetrated the tropopause and entered the stratosphere reaching as high as 


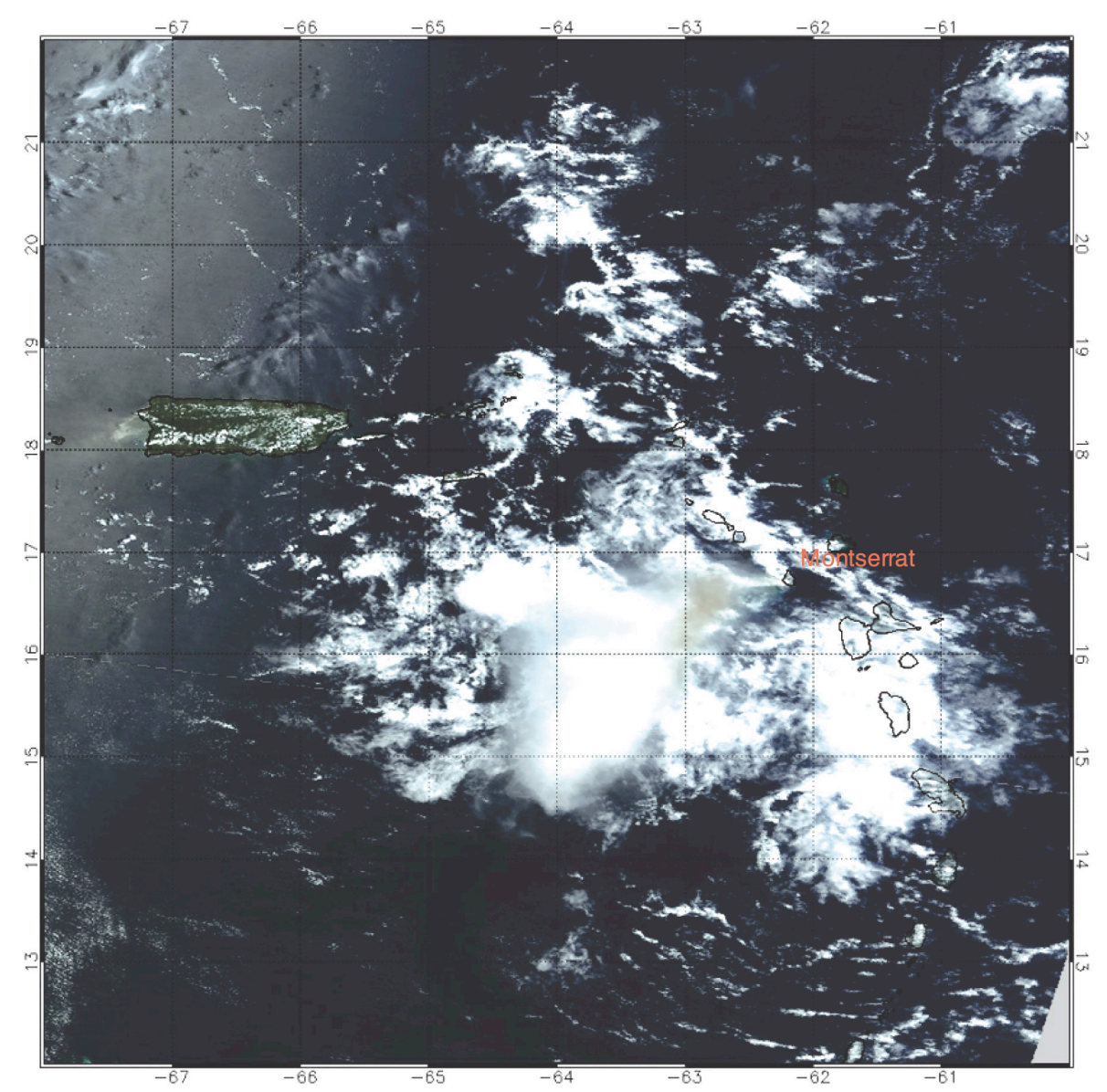

Fig. 1. MODIS-Terra image of the Soufrière Hills eruption cloud acquired at 15:15 UT on 20 May 2006. The colour enhancement was the following: $\mathrm{R}=\mathrm{B}$ and $1(0.62-0.67 \mu \mathrm{m}), \mathrm{G}=\mathrm{B}$ and $4(0.54-0.57 \mu \mathrm{m}), \mathrm{B}=\mathrm{B}$ and $3(0.46-0.48 \mu \mathrm{m})$. In this enhancement (sometimes referred to as "true-colour", since the channel assignments match the red, green and blue parts of the light spectrum) clouds appear white or grey, the ocean appears in shades of blue and the land in shades of green, yellow and brown. Particulates in the cloud, or gases that preferentially absorb more strongly in one band or another bring colour to that region of the image.

$20 \mathrm{~km}$. There was also a large quantity of ice in the eruption cloud. A MODIS-Terra image obtained about $6 \mathrm{~h}$ after the eruption shows a large and high cloud moving westwards away from the volcano on Montserrat (Fig. 1). There is a slight yellowish discoloration ${ }^{1}$ on the eastern flank of the eruption cloud, which we assume is due to a higher proportion of volcanic ash there. The cloud also contained copious amounts of $\mathrm{SO}_{2}$ and some $\mathrm{HCl}$.

\footnotetext{
${ }^{1}$ Experience with analysing MODIS images of volcanic ash using the "true-colour" enhancement (see caption to Fig. 1 for details) leads us to believe that the discoloration is due to particulate matter and that this is most likely volcanic ash.
}

\section{Satellite measurements of the volcanic cloud con- stituents}

\subsection{Early evolution - SEVIRI measurements}

The initial phase of the eruption was not captured well by the afternoon polar orbiting satellite instruments due to timing with the eruption onset. However, sensors on board two geosynchronous satellites (GOES-W and MSG-SEVIRI) and the MODIS sensor on board the morning EOS-Terra satellite were able to image the eruption cloud within the first few hours of the eruption.

$\mathrm{SO}_{2}$ column retrievals were carried out using the SEVIRI channels centred at 6.7, 7.3 and $11 \mu \mathrm{m}$ based on the methodology described by Prata and Kerkmann (2007). The SEVIRI 7.3 $\mu \mathrm{m}$ channel covers a strong $\mathrm{SO}_{2}$ absorption feature and Prata et al. (2003) have shown that this spectral region can be used to determine $\mathrm{SO}_{2}$ columns, provided the $\mathrm{SO}_{2}$ is above $\sim 3 \mathrm{~km}$, and interference from water vapour is small. 

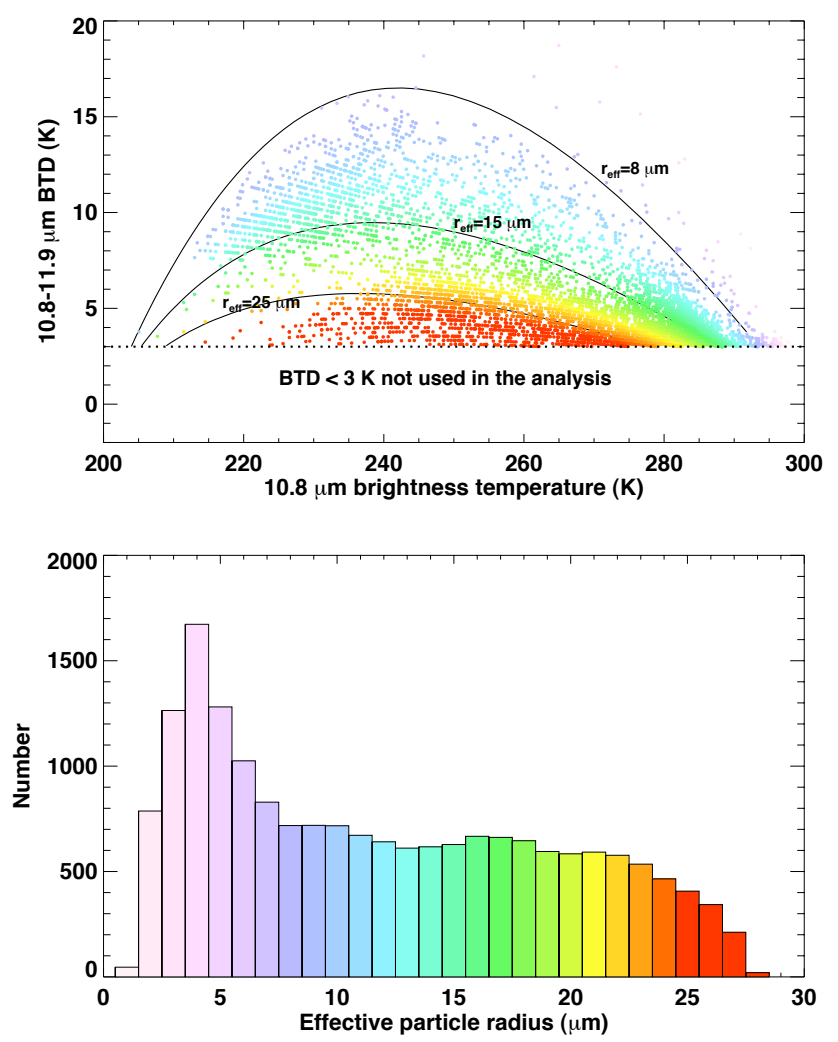

Fig. 2. Ice mass retrievals from SEVIRI 11 and $12 \mu \mathrm{m}$ data. Observed $11-12 \mu \mathrm{m}$ brightness temperature difference (BTD in K) vs. $11 \mu \mathrm{m}$ brightness temperature (K) for 9 consecutive SEVIRI images spanning the time interval 19:30 to 21:30 UT on 20 May 2006 (top panel). The points are colour coded to show particle size; lilac represents small particles $(<8 \mu \mathrm{m})$ and red represents larger particles $(>25 \mu \mathrm{m})$. The effective particle size histogram for $\sim 50000$ data points is also shown (bottom panel).

Ice can be inferred from brightness temperature differences (BTDs) between SEVIRI 11 and $12 \mu \mathrm{m}$ channels. Methods for retrieving cloud microphysics from satellite infrared measurements have been described by Inoue (1985), Wu (1987), Prata (1989), Parol et al. (1991), Prata and Barton (1993), Wen and Rose (1994), Rose et al. (1995) and Prata and Grant (2001), among others. The technique used here follows closely that described by Wen and Rose (1994) and Prata and Grant (2001) in which Mie scattering code is used to determine phase functions and absorption/scattering parameters for prescribed particle size distributions - the Gamma distribution (Deirmendjian, 1969) is used, and prescribed refractive indices of ice (Warren, 1984) averaged over the bandpasses of the SEVIRI channels. A discrete ordinate radiative transfer model (Stamnes et al., 1988) is applied to determine the 11 and $12 \mu \mathrm{m}$ brightness temperatures. The observations of 11 and $12 \mu \mathrm{m}$ brightness temperatures are then used with the model values in an inversion algorithm that generates effective particle radius and infrared optical depth. Integration of these values over all image pixels provides an estimate of ice mass in the cloud.

The retrievals are carried out on an image-by-image basis and ice masses are calculated over all pixels for which the $\mathrm{BTD}>3 \mathrm{~K}$. This criterion is used to reject pixels with either high infrared opacity, or very transparent pixels, for which the cloud fraction is small. Retrieval of cloud parameters for highly opaque or highly transparent pixels is subject to large errors (Prata and Barton, 1993). Figure 2 shows the ice retrieval results for 9 images, spanning the time interval from 19:30 to 21:30 UT on 20 May 2006. The top panel shows BTD vs. $11 \mu \mathrm{m}$ brightness temperature observations and modelled behaviour for three different effective particle sizes (solid black line). The particle sizes are colour coded with smallest sizes $(1 \mu \mathrm{m})$ in lilac and largest sizes $(28 \mu \mathrm{m})$ in red. The bottom panel of this figure shows the retrieved particle size distribution for $\sim 50000$ data points. The observations and the model results suggest that largest ice particle sizes give rise to smallest BTDs. Similar results would be expected for water droplets, however it is more likely that the particles are in the ice phase as cloud top temperatures are in the range $200-220 \mathrm{~K}$. Ash particles cannot produce positive BTDs, irrespective of their size (Prata, 1989; Wen and Rose, 1994) and it is unlikely that there are any other chemical species or particle types (soot or windblown dust) present in the cloud.

A sequence of 97 SEVIRI retrievals of $\mathrm{SO}_{2}$ column and ice mass for the time period 11:00 UT, 20 May to 11:00 UT, 21 May are presented as a movie loop (Movie 1 - http://www.atmos-chem-phys.net/7/5093/2007/ acp-7-5093-2007-supplement.zip) to show the rapid movement of the $\mathrm{SO}_{2}$ and the remarkable changes in the mass of ice and $\mathrm{SO}_{2}$ as the cloud evolves. Figure 3 shows the temporal development of the ice and $\mathrm{SO}_{2}$ masses for the first $34 \mathrm{~h}$ after the eruption. This clearly shows the $\mathrm{SO}_{2}$ mass increasing as the ice mass decreases, and the peak in $\mathrm{SO}_{2}$ mass occurs $\sim 8 \mathrm{~h}$ after the peak in ice mass.

The effective ice cloud particle radii may have been reduced by ash pollution (Rosenfeld, 2000), and the abundance of ice in the cloud supports previous work on the ubiquity of ice in eruption clouds (Rose et al., 1995; Tupper et al., 2004), especially at tropical latitudes. The ice must also have penetrated the tropopause and moistened the stratosphere, with potential radiative impacts and consequences for the stratospheric water vapour budget. The temporal development of the eruption cloud (Fig. 3) suggest that in the early phase, the ice masked the $\mathrm{SO}_{2}$ signature, probably because much of the $\mathrm{SO}_{2}$ gas was sequestered by the ice particles, only to sublimate at a later stage as the ice evaporated. Approximately $2 \mathrm{Tg}$ of ice is evident $\sim 20 \mathrm{~h}$ after the initial eruption (Fig. 3). The ice may also have played a role in depleting the cloud of $\mathrm{HCl}$.

Minimum temperatures at the centre of the eruption cloud were $200 \mathrm{~K}$, while there is evidence of warmer temperatures $(218 \mathrm{~K})$ near the cold core suggesting overshooting and pen- 
etration into the stratosphere. Based on a radiosonde ascent from Guadeloupe $\left(16.218^{\circ} \mathrm{N}, 61.517^{\circ} \mathrm{W}\right)$ at 12:00 UT on 20 May, the cloud-top temperatures imply geopotential heights of $17.5 \mathrm{~km}(200 \mathrm{~K})$ and $20.6 \mathrm{~km}(218 \mathrm{~K})$. A tropopause can be identified between 16.3 and $17.2 \mathrm{~km}$ in this profile.

The development of the eruption column and subsequent injection of $\mathrm{SO}_{2}$ into the atmosphere occurred within the relatively short time frame of $15 \mathrm{~min}$. The eruption cloud appears to have penetrated the stratosphere in the first $15 \mathrm{~min}$ and then experienced rapid transport towards the WSW at speeds of $15 \mathrm{~ms}^{-1}$ at a likely maximum altitude of $20 \mathrm{~km}$. Some parts of the cloud travel further south, reaching Venezuela and further inland towards Colombia. This more southerly branch of the cloud was lower in the atmosphere, below the tropopause, causing some disruption to aviation across the Caribbean. Figure 4 shows the $\mathrm{SO}_{2}$ and ice cloud at four different times during 20-21 May. At the start (top panels) the $\mathrm{SO}_{2}$ is completely obscured (grey areas on leftmost panels) by cloud. The regions of semi-transparent cloud are revealed by very large positive BTDs (indicated in white on the scale of the right-most panels). By 18:00 UT on 20 May the $\mathrm{SO}_{2}$ content of the cloud is fully revealed by the SEVIRI data. A maximum loading of $0.177 \pm 0.04 \mathrm{Tg}\left(\mathrm{SO}_{2}\right)$ is estimated by SEVIRI at 06:15 UT, 21 May (Fig. 4, bottomright panel). We caution that the SEVIRI algorithm has yet to be validated and interference from clouds may produce errors as large as $30 \%$ in certain circumstances. The $\mathrm{SO}_{2}$ cloud reached $72^{\circ} \mathrm{W}$ by 11:00 UT, 21 May and subsequently moved out of the field-of-view of the SEVIRI instrument.

\subsection{Later evolution - AIRS, OMI and MLS measurements}

Beyond the first day, the A-train polar-orbiters Aqua (AIRS) and Aura (OMI and MLS) were able to capture and detail the movement of the $\mathrm{SO}_{2}$ cloud as it rapidly moved westwards in the stratospheric winds. Algorithms for determining $\mathrm{SO}_{2}$ from AIRS (Carn et al., 2005) exploit the strong $\mathrm{SO}_{2}$ anti-symmetric stretch absorption feature centred near $7.3 \mu \mathrm{m}\left(1363 \mathrm{~cm}^{-1}\right)$. This band is difficult to use to detect $\mathrm{SO}_{2}$ because water vapour absorbs strongly across the band, however, accurate retrievals can be made provided the $\mathrm{SO}_{2}$ is above the water vapour, nominally above $\sim 3 \mathrm{~km}$ (Prata et al., 2003). Furthermore, the masking of lower tropospheric $\mathrm{SO}_{2}$ by water vapour in this band provides a natural filter for estimating upper troposphere/lower stratosphere (UTLS)only $\mathrm{SO}_{2}$, the component that has highest impact on climate. Figure 5 shows AIRS $\mathrm{SO}_{2}$ column amounts (in DU) for a sequence of 6 days after the eruption. Overlaid onto this Figure are 6 trajectories determined from the HYSPLIT model (Draxler and Rolph, 2003). The trajectories were initialised at 11:00 UT on 20 May and plotted at $6 \mathrm{~h}$ intervals. The best correspondence between the location of the cloud on 26 May and HYSPLIT is for the trajectory at $20 \mathrm{~km}$. Lower trajectories either move the cloud too slowly, too far north or too far south. AIRS and OMI tracked a part of the $\mathrm{SO}_{2}$ cloud south-

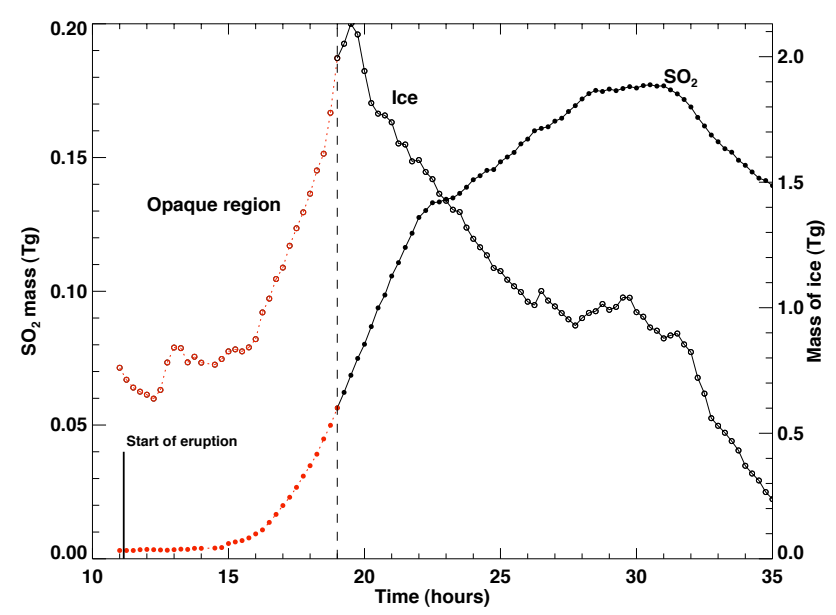

Fig. 3. Temporal development of the $\mathrm{SO}_{2}$ total column and ice mass (both in $\mathrm{Tg}$ ) derived from SEVIRI data.

wards or SSW across Venezuela and Colombia. This portion fits a trajectory at $15 \mathrm{~km}$. The best estimate of the stratospheric $\mathrm{SO}_{2}$ burden from AIRS data is $0.178 \pm 0.02 \mathrm{Tg}\left(\mathrm{SO}_{2}\right)$. The abruptness of the eastern edge of the $\mathrm{SO}_{2}$ cloud noticeable in the sequence is due to the narrowness of the AIRS swath.

The Soufrière Hills $\mathrm{SO}_{2}$ cloud was also analysed using an updated $\mathrm{OMI} \mathrm{SO}_{2}$ algorithm optimised for large $\mathrm{SO}_{2}$ column amounts (Krotkov et al., 2006). OMI detected the $\mathrm{SO}_{2}$ cloud on 20 May and continued to track the cloud until 11 June, when it was located over the Indian Ocean (Movie 2 - http://www.atmos-chem-phys.net/7/5093/2007/ acp-7-5093-2007-supplement.zip). OMI uses UV reflected sunlight to determine $\mathrm{SO}_{2}$ column amount and therefore cannot detect at night; however the greater swath width and superior accuracy of OMI complement retrievals from AIRS and SEVIRI. The peak burden measured by OMI was $\sim 0.22 \mathrm{Tg}\left(\mathrm{SO}_{2}\right)$ (see Carn et al., 2007); this difference from the AIRS result may reflect the contiguous spatial coverage of OMI that permitted mapping of the entire cloud. Figure 6 shows the $\mathrm{OMI} \mathrm{SO}_{2}$ volume mixing ratio (vmr) determined by assuming that the cloud was centred at $\sim 20 \mathrm{~km}$ and had a vertical extent of $2 \mathrm{~km}$, which is in accord with CALIPSO lidar estimates (Carn et al., 2007) and with FLEXPART modelling (see next section). $\mathrm{SO}_{2}$ vmrs at $20 \mathrm{~km}$ vary from $\sim 0.5 \mathrm{ppm}$ to $\sim 5 \mathrm{ppm}$.

$\mathrm{HCl}$ was detected in the plume using retrievals from the Microwave Limb Sounder-MLS (Waters et al., 2006; Froidevaux et al., 2006). The MLS field-of-view of $\sim 30 \mathrm{~km}$ acrosstrack and $\sim 150 \mathrm{~km}$ along-track and the sparse sampling of the moving gas cloud make accurate estimates of the erupted $\mathrm{HCl}$ mass difficult. Thus we have accumulated the $\mathrm{HCl}$ retrievals at $68.13 \mathrm{hPa}(\sim 20 \mathrm{~km})$ over the period 1-31 May and within the geographic region bounded by $180^{\circ} \mathrm{W}$ to $60^{\circ} \mathrm{W}$ and $0^{\circ}$ to $20^{\circ} \mathrm{N}$ and illustrated the result in Fig. 7. The 

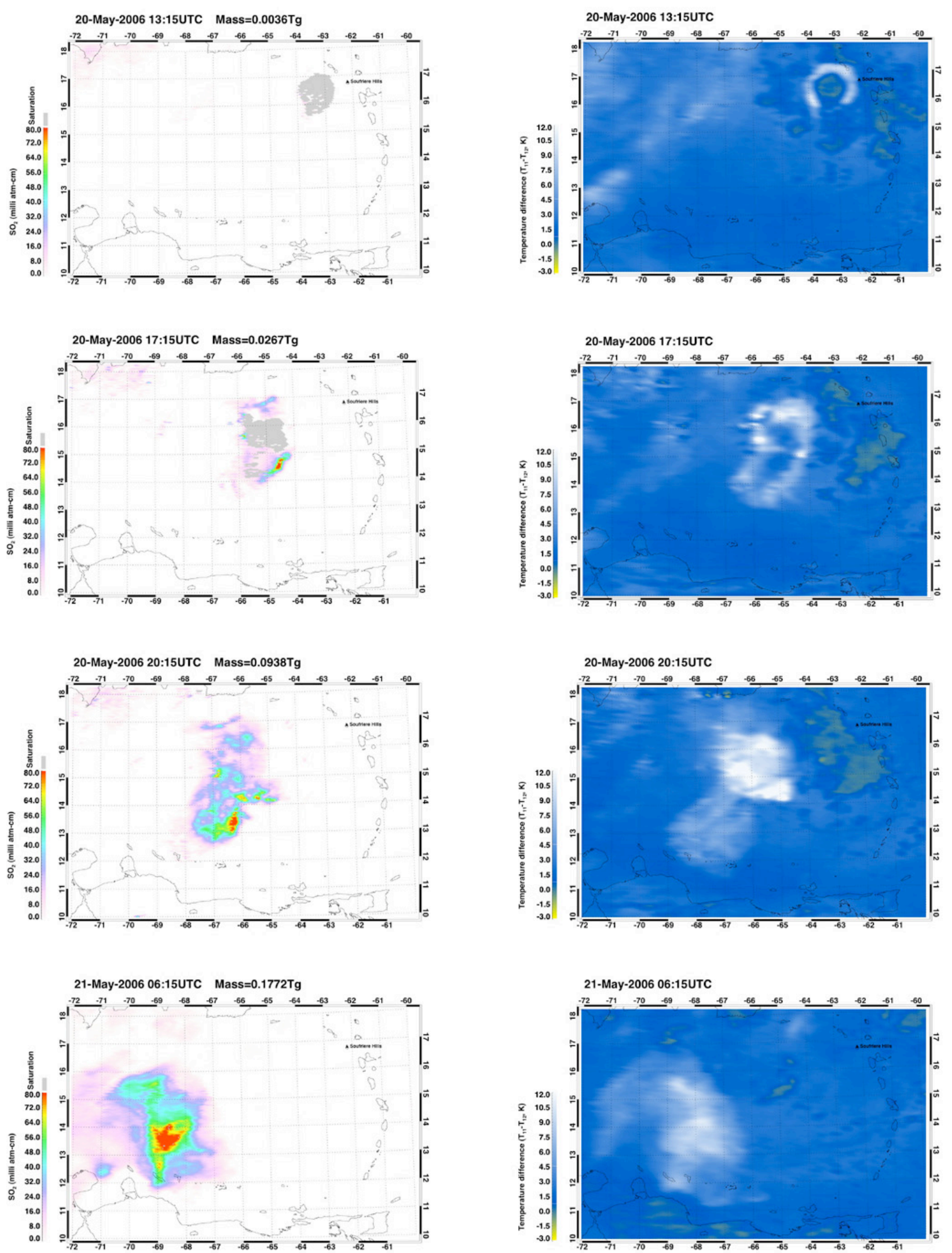

Fig. 4. Column $\mathrm{SO}_{2}$ derived from MSG-SEVIRI (left-most panels) and 11-12 $\mu \mathrm{m}$ BTDs (right-most panels) for four different times: 06:15 UT, 20 May, 17:15 UT, 20 May, 20:15 UT, 20 May and 06:15 UT, 21 May. Grey coloured areas are regions of the cloud where SO 2 cannot be retrieved because the cloud is too opaque. 


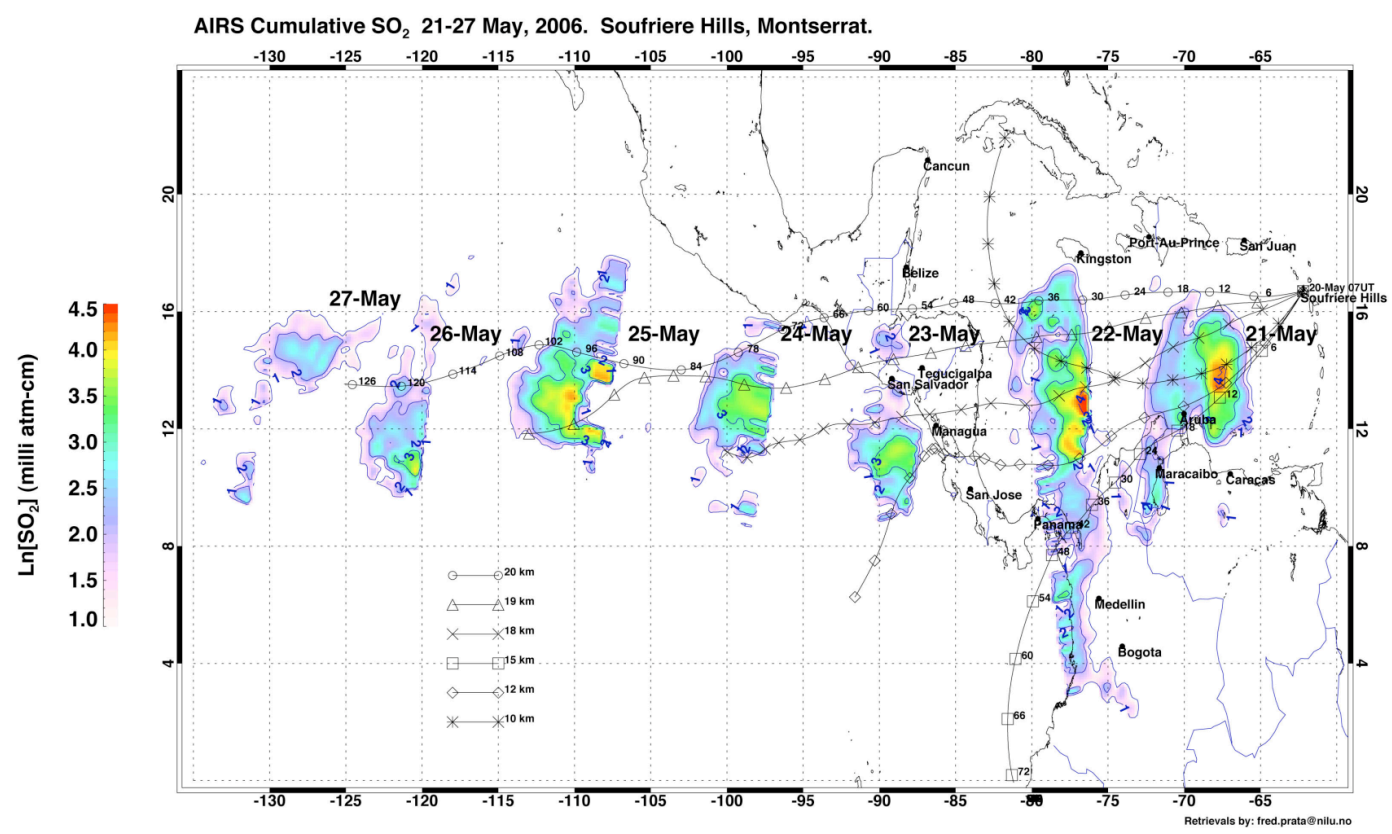

Fig. 5. AIRS $\mathrm{SO}_{2}$ total column retrievals for 21-26 May 2006. Also shown are HYSPLIT trajectories at six different altitudes. The trajectory at $20 \mathrm{~km}$ matches the AIRS observations best.

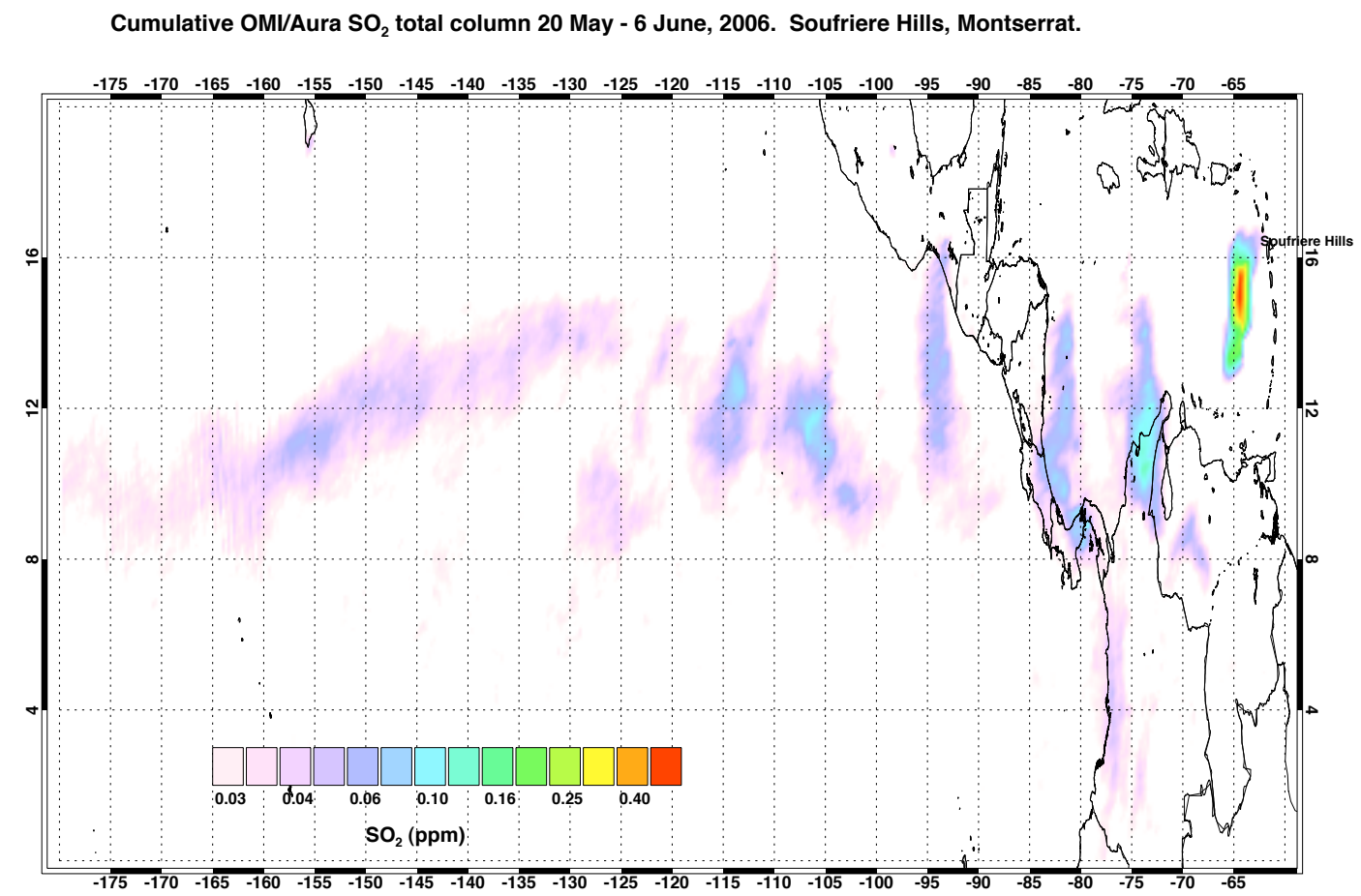

Fig. 6. $\mathrm{OMI} \mathrm{SO} 2$ volume mixing ratio calculated for a plume at $20 \mathrm{~km}$ with a width of $2 \mathrm{~km}$ for the period 20 May to 6 June.

maximum $\mathrm{HCl}$ vmr occurs later than the maximum $\mathrm{SO}_{2} \mathrm{vmr}$ and gas ratios $\mathrm{HCl}: \mathrm{SO}_{2}$ vary from 0.03 to 0.1 . This ratio is smaller than that inferred for Pinatubo and El Chichón of $\sim 0.2-0.25$ (Westrich and Gerlach, 1992), but similar to that found for the stratospheric portion from Pinatubo of $\sim 0.1$
(Mankin et al., 1992) and for the Hekla 2000 volcanic plume of $\sim 0.07$ (Rose et al., 2006). The lack of coincidence between the $\mathrm{OMI} \mathrm{SO}_{2}$ and MLS $\mathrm{HCl}$ vmrs may be due to the different processing methods (the MLS data have been accumulated) or possibly due to the inadequate sampling of the 


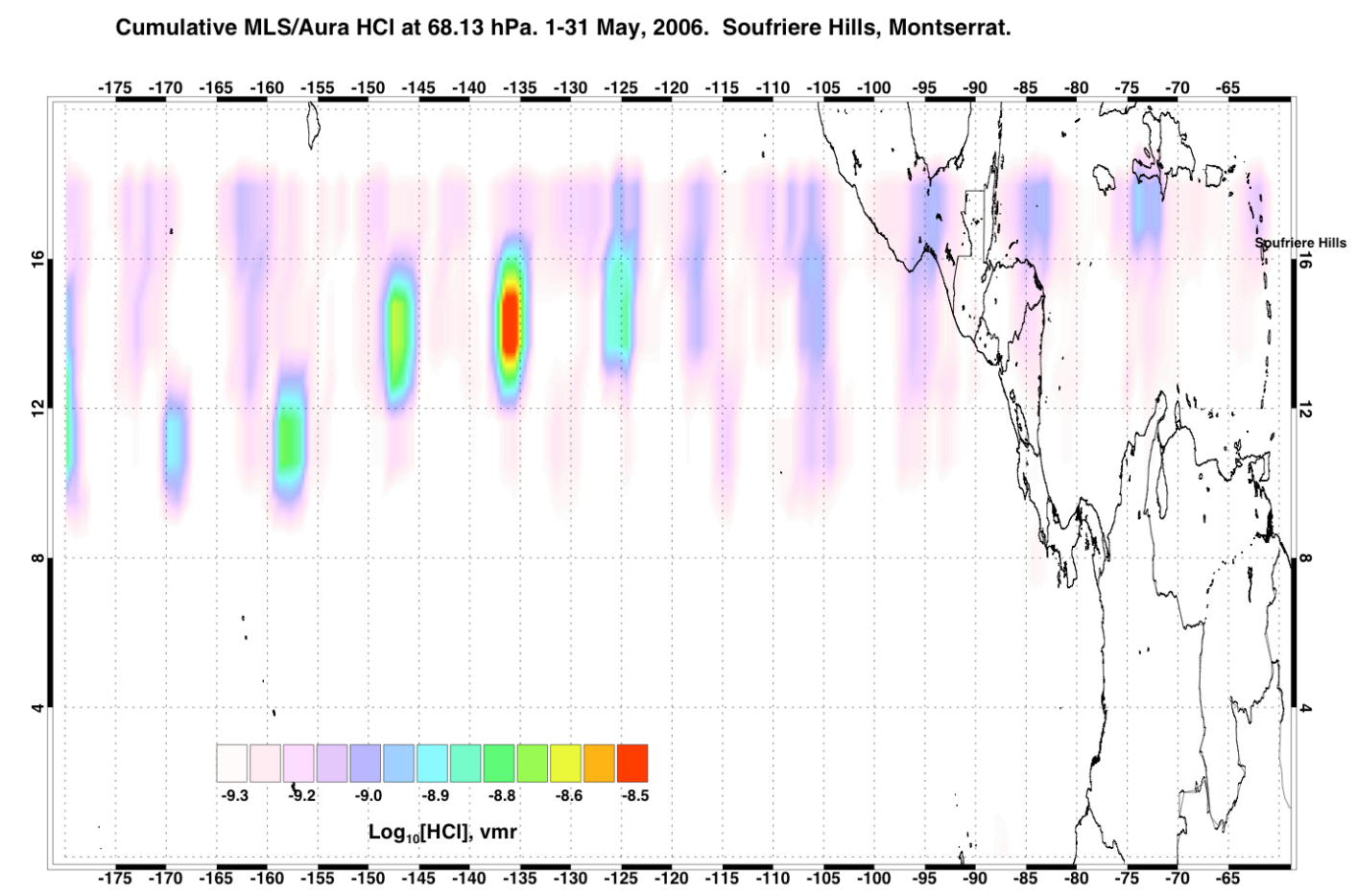

Fig. 7. $\mathrm{MLS} \mathrm{HCl}$ volume mixing ratios at $\sim 68 \mathrm{hPa}(\sim 20 \mathrm{~km})$ for the period $20-31$ May.

cloud by the MLS as the cloud travelled westwards. The MLS has both coarser ground field of view resolution and poorer sampling than the OMI so it is possible that it did not sample the position of the maximum $\mathrm{HCl}$ in the cloud.

The small mass of $\mathrm{HCl}$, particularly at the early stages of the cloud's evolution could also suggest that "scrubbing" of $\mathrm{HCl}$ is occurring, either through scavenging by ice or by removal in condensed supercooled water (Tabazedeh and Turco, 1993). Assuming that the $\mathrm{HCl}$ is coincident with the $\mathrm{SO}_{2}$ cloud, the mass of $\mathrm{HCl}$ erupted is $\sim 3-10 \mathrm{kt}$, which is much smaller than might be expected based on petrologic arguments (Gerlach et al., 1996) or from observations in the Soufrière Hills volcano tropospheric plume (Edmonds et al., 2002).

\section{Modelling the dispersion of the cloud}

To simulate the dispersion of the $\mathrm{SO}_{2}$ cloud, calculations with the Lagrangian particle dispersion model FLEXPART (Stohl et al., 1998, 2005) were made (Movie 3 - http://www.atmos-chem-phys.net/7/5093/2007/ acp-7-5093-2007-supplement.zip). FLEXPART was originally developed to simulate the dispersion of dangerous substances from point sources and was validated for such applications with data from continental-scale tracer experiments (Stohl et al., 2005). Since then it has been applied in a large number of studies on atmospheric transport, for instance intercontinental pollution transport or stratosphere-troposphere exchange. FLEXPART is a pure transport model and no removal processes were considered here. FLEXPART was driven with operational analyses from the European Centre for Medium-Range Weather Forecasts with $1^{\circ} \times 1^{\circ}$ resolution (derived from T319 spectral truncation) and a nest with $0.36^{\circ} \times 0.36^{\circ}$ resolution (derived from T799 spectral truncation) in the region $108-27^{\circ} \mathrm{W}$ and $9-54^{\circ} \mathrm{N}$. The resolution of the 91-level ECMWF data in the altitude range of interest here, $17-20 \mathrm{~km}$, is about $500 \mathrm{~m}$. In addition to the analyses at 00:00, 06:00, 12:00 and 18:00 UTC, 3-h forecasts at intermediate times (03:00, 09:00, 15:00, 21:00 UTC) were used. Since the altitude of the $\mathrm{SO}_{2}$ injection was not well known beforehand, FLEXPART scenarios with injections at different $500 \mathrm{~m}$ altitude intervals were made and the model results were compared with the satellite $\mathrm{SO}_{2}$ retrievals. Finally, a simulation injecting $0.027,0.044,0.108 \sim \mathrm{Tg}\left(\mathrm{SO}_{2}\right)$ into altitude bins of $17.5-18,18-18.5$, and $18.5-19.5 \mathrm{~km}$ was made, which most closely matched the observed plume.

In order to account for loss of $\mathrm{SO}_{2}$ due to chemical conversion of the $\mathrm{SO}_{2}$ to $\mathrm{H}_{2} \mathrm{SO}_{4}$, a simple exponential decay factor was applied, with an e-folding time of 24 days (Guo et al., 2004). Comparing the two movie loops of the OMI observations (Movie 2 - http://www.atmos-chem-phys.net/7/5093/ 2007/acp-7-5093-2007-supplement.zip) with the FLEXPART simulations (Movie 3 - http://www.atmos-chem-phys. net/7/5093/2007/acp-7-5093-2007-supplement.zip) it can be seen that in the initial phase there is good correspondence. By 21:00 UT on 23 May there is still very good correspondence between OMI and FLEXPART. OMI shows the cloud 
as being broader, but the column amounts are quite close. A day later and some noticeable differences are apparent. FLEXPART has moved the cloud further north than OMI and the cloud is still broader in the OMI data. Both movies show a narrow trailing edge ending near the coast of Costa Rica and Panama. On 27 May at 21:00 UT the cloud has developed a SW-NE tilt, noticeable in both OMI and FLEXPART. FLEXPART has moved the cloud further west and north compared to OMI observations. One reason for the differences in cloud shape between FLEXPART and OMI is due to the sampling differences. FLEXPART data are portrayed at 3-h time intervals, while the OMI sampling is variable and in some cases shows the cloud development over $22 \mathrm{~h}$. FLEXPART simulations analysed over a similar time interval $(\sim 22 \mathrm{~h})$ show a much broader and longer cloud, in better agreement with the OMI observations. The faster movement of the cloud and its more northerly position in FLEXPART relative to OMI are likely due to cumulative errors in the wind field over the 12 day forecast period shown in addition to any model deficiencies. The correspondence between the column amounts in FLEXPART and OMI after 10 days of travel is encouraging and suggests the e-folding time of 24 days for chemical loss of $\mathrm{SO}_{2}$ is reasonable.

The simulation confirms that the $\mathrm{SO}_{2}$ observed by the satellite instruments was indeed stratospheric, located at potential temperatures $>380 \mathrm{~K}$, or altitudes $>17 \mathrm{~km}$. A vertical section through the cloud on 7 June 2006, as it neared the Philippines $\left(\sim 127^{\circ} \mathrm{E}\right)$ is shown in Fig. 8. The fullwidth at half-maximum of the layer is $\sim 2 \mathrm{~km}$, the height of the maximum concentration is $20 \mathrm{~km}$ and it is located between $17-21^{\circ} \mathrm{N}$. This is further north than OMI retrievals suggest $\left(\sim 10^{\circ} \mathrm{N}\right)$, but the height and layer depth agree well with CALIPSO first-light data. The section also suggests a double-layer structure and a slight tilt with latitude. Since the material was initially injected below $19.5 \mathrm{~km}$, there must have been substantial uplift in the ascending branch of the Brewer-Dobson circulation, indicating future global redistribution of the $\mathrm{SO}_{2}$ in the stratospheric overworld. The fate of the $\mathrm{SO}_{2}$ will likely be complete conversion to aqueous sulphuric acid in the stratosphere where it will remain for 1-2 years.

\section{Discussion}

The combined use of three different satellite-based measurements of the total column of $\mathrm{SO}_{2}$ provide a high degree of confidence that $0.1 \pm 0.01 \mathrm{Tg}$ (S) was injected into the stratosphere from the 20 May 2006 eruption of Soufrière Hills volcano. A Lagrangian model confirms that the $\mathrm{SO}_{2}$ layer travelled rapidly westwards at a height of $\sim 20 \mathrm{~km}$. The layer thickness $(\sim 2 \mathrm{~km}$, full width half-maximum) and height agree with first-light observations from the CALIPSO lidar. The typical time constant for conversion of $\mathrm{SO}_{2}$ to $\mathrm{H}_{2} \mathrm{SO}_{4}$ is $\sim 3$ weeks, so much of this layer is likely to be

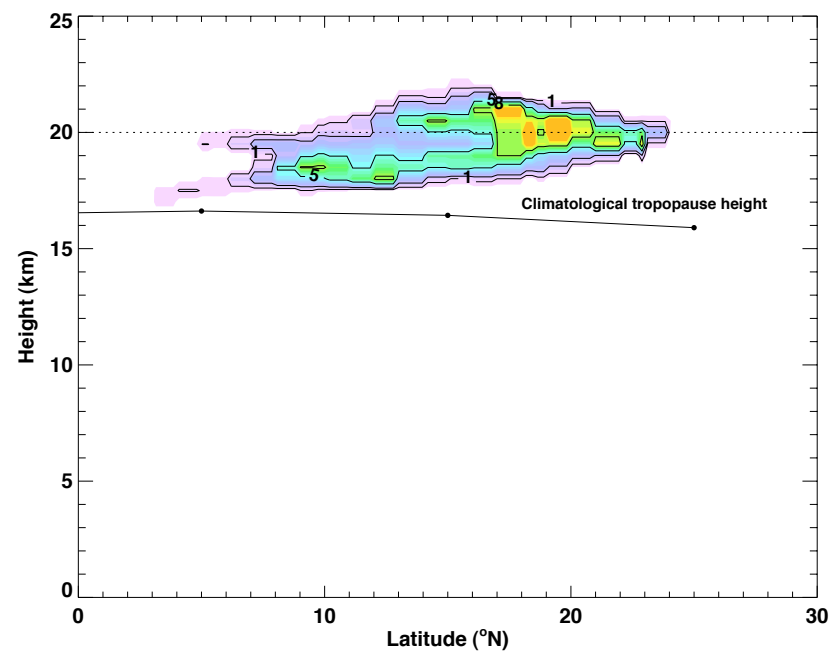

Fig. 8. Vertical section through the FLEXPART model simulation near $127^{\circ} \mathrm{E}$ showing $\mathrm{SO}_{2}$ concentrations in units of $\mu \mathrm{g} \mathrm{m}^{-3}$. The climatological lapse-rate tropopause height for May/June is also shown.

sulphate. The ability of OMI/AIRS to track the clouds for 23 days and over more than $18000 \mathrm{~km}$ suggests these instruments will be very useful for providing better estimates of volcanic emissions and assist Volcanic Ash Advisory Centres (VAACs) to locate these hazardous clouds. It is worth noting that as the cloud approached the busy Australian/Japan flight routes, advisories were issued to the Meteorological Watch Offices and airlines based on these satellite $\mathrm{SO}_{2}$ retrievals. The airline industry chose to fly underneath the cloud, rather than divert flights and incur extra fuel costs. No encounters were reported.

The AIRS $7.3 \mu \mathrm{m}$ band is most sensitive to UTLS $\mathrm{SO}_{2}$, where interference from water vapour effects is minimised and thus the AIRS $\mathrm{SO}_{2}$ is indicative of $\mathrm{SO}_{2}$ likely to have an impact on global climate. Climate models use Aerosol Optical Depth (AOD) or indices of volcanic eruption magnitude, as measures of the radiative effect of stratospheric aerosols. AOD is linearly related to the total column sulphate (Kiel and Briegleb, 1993), and the radiative forcing is linearly related to AOD (Hansen et al., 2002). These new satellite estimates of $\mathrm{SO}_{2}$ column amount can be used directly in climate models to assess the impact on atmospheric radiation. However, since it is the sulphate aerosol that causes the major climate effect ( $\mathrm{SO}_{2}$ and ash also have climate effects), there is still a need to use a chemical model to convert $\mathrm{SO}_{2}$ to $\mathrm{H}_{2} \mathrm{SO}_{4}$ aerosol.

The stratospheric transport and spread of this $\mathrm{SO}_{2}$ cloud has similarities to that of Pinatubo and Hudson in 1991, albeit both produced much more $\mathrm{SO}_{2}$. The Pinatubo $\mathrm{SO}_{2}$ cloud was observed as a discrete cloud travelling predominantly westwards and spreading laterally (see Fig. 4 of Guo et al., 2004). The Hudson $\mathrm{SO}_{2}$ cloud also travelled as a discrete cloud but 
with less lateral spread and greater zonal elongation as it travelled eastwards at the outer fringe of the southern polar vortex (Doiron et al., 1991; Schoeberl et al., 1993; Barton et al., 1992). It could be observed in TOMS data for 19 days (Doiron et al., 1991) and Prata et al. (2003) show the movement of the $\mathrm{SO}_{2}$ cloud in TOVS retrievals for 9 days. Once these $\mathrm{SO}_{2}$ clouds reach the stratosphere, rapid transport and dispersion ensure that they will spread globally and convert to $\mathrm{H}_{2} \mathrm{SO}_{4}$ aerosol with an e-folding time of the order $\sim 3$ weeks. The climate response of these kinds of stratospheric injections is governed by the quantity of $\mathrm{SO}_{2}$ injected, as well as by the latitude of injection.

Serious concern over the warming effects of increasing $\mathrm{CO}_{2}$ levels in the atmosphere has led to a proposal to inject $\mathrm{S}$ into the tropical stratosphere as a geo-engineering tool for cooling the climate (Crutzen, 2006; Wigley, 2006). An approach like this will rely on knowledge of the current sulphate loading of the stratosphere and means for estimating the loading due to volcanic eruptions, some in very remote locations and with little infrastructure to make reliable $\mathrm{SO}_{2}$ measurements. Applying linear scaling arguments based on the impact of Pinatubo on surface temperatures, viz. $10 \mathrm{Tg}$ (S) produced $\sim 0.6 \mathrm{~K}$ surface cooling, the Soufrière Hills $\mathrm{SO}_{2}$ cloud would cause $<0.01 \mathrm{~K}$ of global surface cooling and is unlikely to have any noticeable affect. Less than $10 \mathrm{kt}$ of $\mathrm{HCl}$ was detected in the cloud suggesting that $\mathrm{HCl}$ is efficiently removed and reduces the likelihood of serious ozone depletion from this stratospheric injection. The long-range transport and dispersion also suggests there would be negligible local effects due to this cloud.

Acknowledgements. The AIRS Science Team are thanked for providing the AIRS level $1 \mathrm{~b}$ geolocated radiance data and the MLS Science Team are thanked for supplying the v5.2 $\mathrm{HCl}$ retrievals. The three anonymous reviewers of this paper are thanked for their insightful comments and for suggesting improvements to our paper.

Edited by: R. MacKenzie

\section{References}

Barton, I. J., Prata, A. J., Watterson, I. G., and Young, S. A.: Identification of the Mt. Hudson volcanic cloud over SE Australia, Geophys. Res. Lett., 19, 1211-1214, 1992.

Bluth, G. J. S., Schnetzler, C. C., Krueger, A. J., and Walter, L. S.: The contribution of explosive volcanism to global atmospheric sulphur dioxide concentrations, Nature, 366, 327-329, 1993.

Carn, S. A., Krotkov, N. A., Yang, K., Hoff, R. M., Prata, A. J., Krueger, A. J., Loughlin, S. C., and P. F. Levelt: Extended observations of volcanic $\mathrm{SO}_{2}$ and sulphate aerosol in the stratosphere, Atmos. Chem. Phys. Discuss., 7, 2857-2871, 2007, http://www.atmos-chem-phys-discuss.net/7/2857/2007/.

Carn, S. A., Strow, L. L., de Souza-Machado, S., Edmonds, Y., and Hannon, S.: Quantifying tropospheric volcanic emissions with AIRS: the 2002 eruption of Mt. Etna (Italy), Geophys. Res. Lett., 32(2), L02301, doi:10.1029/2004GL021034, 2005.
Crutzen, P.: Albedo enhancement by stratospheric sulphur injections: A contribution to resolve a policy dilemma?, Climatic Change, 77, 3-4, 211-220, doi:10.1007/s10584-006-9101y, 2006.

Deirmendjian, D.: Electromagnetic scattering on spherical polydispersions, Elsevier, 290 pp., 1969.

Deshler, T., Andersen-Sprecher, R., Jager, H., Barnes, J., Hofmann, D. J., Clemensha, B., Simonich, D., Osborn, M., Grainger, R. G., and Godin-Beekmann, S.: Trends in the nonvolcanic component of stratospheric aerosol over the period 1971-2004, J. Geophys. Res., 111, D10201, doi:10.1029/2005JD006089, 2006.

Doiron, S. D., Bluth, G. J. S., Schnetzler, C. C., Krueger, A. J., and Walter, L. S.: Transport of Cerro Hudson $\mathrm{SO}_{2}$ clouds, EOS Trans AGU, 72, 489-498, 1991.

Draxler, R. R. and Rolph, G. D.: HYSPLIT (Hybrid Single-Particle Lagrangian Integrated Trajectory) Model access via NOAA ARL READY Website (http://www.arl.noaa.gov/ready/hysplit4.html), NOAA Air Resources Laboratory, Silver Spring, MD, USA, 2003.

Edmonds, M., Pyle, D., and Oppenheimer, C.: $\mathrm{HCl}$ emissions at Soufrière Hills Volcano, Montserrat, West Indies, during a second phase of dome building: November 1999 to October 2000, B. Volcanol., 64, 21-30, 2002.

Froidevaux, L., Livesey, N. J., Read, W. G., et al.: Early Validation Analyses of Atmospheric Profiles From EOS MLS on the Aura Satellite, IEEE T. Geosci. Remote, 45(5), 1106-1121, 2006.

Gerlach, T. M., Westrich, H. R., and Symonds, R. B.: Pre-eruption vapour in magma of the climactic Mt. Pinatubo eruption: Source of the giant stratospheric sulphur dioxide cloud, in: Fire and Mud, Eruptions and Lahars of Mount Pinatubo, Philippines, edited by: Newhall and Punongbayan, University of Washington Press, Seattle, 415-433, 1996.

Guo, S., Bluth, G. J. S., Rose, W. I., Watson, M., and Prata, A. J.: Re-evaluation of $\mathrm{SO}_{2}$ release of the 15 June 1991 Pinatubo eruption using ultraviolet and infrared satellite sensors, Geochem. Geophy. Geosy., 5(4), Q04001, doi:10.1029/2003GC000654, 2004.

Halmer, M. M., Schmincke, H.-U., and Graf, H.-F.: The annual volcanic gas input into the atmosphere, in particular into the stratosphere: a global data set for the past 100 years, J. Volcanol. Geoth. Res., 115, 511-528, 2002.

Hansen, J., Lacsis, A., Ruedy, R., and Sato, M.: Potential climate impact of Mount Pinatubo eruption, Geophys. Res. Lett., 19(2), 21-218, 2002.

Inoue, T.: On the transparent and effective emissivity determination of semitransparent clouds by bispectral measurements in the $10 \mu \mathrm{m}$ region, J. Meteorol. Soc. Jpn., 63, 88-98, 1985.

Kiehl, J. T. and Briegleb, B. P.: The relative roles of sulphate aerosols and greenhouse gases in climate forcing, Science, 260, 311-314, 1993.

Krotkov, N. A., Carn, S. A., Krueger, A. J., Bhartia, P. K., and Yang, K.: Band Residual Difference algorithm for retrieval of $\mathrm{SO}_{2}$ from the Aura Ozone Monitoring Instrument (OMI), IEEE T. Geosci. Remote Sensing, 44(5), 1259-1266, doi:10,1109/TGRS.2005.861932, 2006.

Krueger, A. J., Walter, L. S., Bhartia, P. K., Schnetzler, C. C., Krotkov, N. A., Sprod, I., and Bluth, G. J. S.: Volcanic sulphur dioxide measurements from the total ozone mapping spectrometer instruments, J. Geophys. Res., 100, 14 057-14 076, 1995. 
Mankin, W. G., Coffey, M. T., Goldman, A.: Airborne observations of $\mathrm{SO}_{2}, \mathrm{HCl}$, and $\mathrm{O}_{3}$ in the stratospheric plume of the Pinatubo volcano in July 1991, Geophys. Res. Lett., 19(2), 179-182, 1992.

McGonigle, A. J. S., Oppenheimer, C., Galle, B., Mather, T. A, and Pyle, D. M.: Walking traverse and scanning DOAS measurements of volcanic gas emission rates, Geophys. Res. Lett., 29(20), 1985, doi:10.1029/2002GL015827, 2002.

Parol, F., Buriez, J. C., Brogniez, G., and Fouquart, Y.: Information content of AVHRR channels 4 and 5 with respect to the effective radius of cirrus cloud particles, J. Appl. Meteorol., 30, 973-984, 1991.

Prata, A. J.: Infrared radiative transfer calculations for volcanic ash clouds, Geophys. Res. Lett., 16(11), 1293-1296, 1989.

Prata, A. J. and Barton, I. J.: A multichannel, multiangle method for the determination of infrared optical depth of semi-transparent high cloud from an orbiting satellite, Part 1: Formulation and simulation, J. Appl. Meteorol., 32, 1623-1637, 1993.

Prata, A. J. and Bernardo, C.: Retrieval of volcanic $\mathrm{SO}_{2}$ column abundance from AIRS data, J. Geophys. Res., in press, 2007.

Prata, A. J. and Grant, I. F.: Retrieval of microphysical and morphological properties of volcanic ash plumes from satellite data: Application to Mt. Ruapehu, New Zealand, Q. J. Roy. Meteor. Soc., 127, 2153-2179, 2001.

Prata, A. J. and Kerkmann, J.: Simultaneous retrieval of volcanic ash and $\mathrm{SO}_{2}$ using MSG-SEVIRI measurements, Geophys. Res. Lett., 34, L05813, doi:10.1029/2006GL028691, 2007.

Prata, A. J., O'Brien, D. M., Rose, W. I., and Self, S.: Global, long-term sulphur dioxide measurements from TOVS data: A new tool for studying explosive volcanism and climate, Volcanism and the Earth's Atmosphere, Geophysical Monograph, 139, 75-92, doi:10.1029/139GM05, 2003.

Robock, A.: Climatic impact of volcanic emissions, in: State of the Planet, edited by: Sparks, R. S. J. and Hawkesworth, C. J., Geophysical Monograph, 150, IUGG Volume 19, (American Geophysical Union, Washington, DC), 125-134, 2004.

Robock, A.: Volcanoes and Climate, Rev. Geophys., 38(2), 191219, 2000.

Rosenfeld, D.: Suppression of rain and snow by urban and industrial air pollution, Science, 287, 1793-1796, 2000.

Rose, W. I., Delene, D. J., Schneider, D. J., Bluth, G. J. S., Krueger, A. J., Sprod, I., McKee, C., Davies, H. L., and Ernst, G. G. J.: Ice in the 1994 Rabaul eruption cloud: Implications for volcano hazard and atmospheric effects, Nature, 375, 477-479, 1995.
Rose, W. I., Millard, G. A., Mather, T. A., et al.: The atmospheric chemistry of a 33-34 hour old volcanic cloud from Hekla Volcano (Iceland): Insights from direct sampling and the application of chemical box modeling, J. Geophys. Res., 111, D20206, doi:10.1029/2005JD006872, 2006.

Schoeberl, M. R., Doiron, S. D., Lait, L. R., Newman, P. A., and Krueger, A. J.: A Simulation of the Cerro Hudson $\mathrm{SO}_{2}$ Cloud, J. Geophys. Res., 98, 2949-2955, 1993.

Stamnes, K., Tsay, S.-C., Wiscombe, W., and K. Jayaweera: Numerically stable algorithm for discrete-ordinate-method radiative transfer in multiple scattering and emitting layered media, Appl. Optics, 27, 2502-2509, 1988.

Stohl, A., Hittenberger, M., and Wotawa, G.: Validation of the Lagrangian particle dispersion model FLEXPART against large scale tracer experiment data, Atmos. Environ., 32, 4245-4264, 1998.

Stohl, A., Forster, C., Frank, A., Seibert, P., and Wotawa, G.: Technical note: The Lagrangian particle dispersion model FLEXPART version 6.2, Atmos. Chem. Phys., 5, 2461-2474, 2005, http://www.atmos-chem-phys.net/5/2461/2005/.

Tabazedeh, A. and Turco, R. P.: Stratospheric chlorine injection by volcanic eruptions: $\mathrm{HCl}$ scavenging and implications for ozone, Science, 260, 1082-1086, 1993.

Tupper, A., Carn, S. A., Davey, J., Kamada, Y., Potts, R. J., Prata, A. J., and Tokuno, M., An evaluation of volcanic cloud detection techniques during recent significant eruptions in the western "Ring of Fire", Remote Sens. Environ., 91, 27-46, 2004.

Warren, S. G.: Optical constants of ice from the ultraviolet to the microwave, Appl. Optics, 23(8), 1206-1225, 1984.

Waters, J. W., Froidevaux, L., Harwood, R. S., et al.: The Earth Observing System Microwave Limb Sounder (EOS MLS) on the Aura satellite, IEEE T. Geosci. Remote, 44(5), 1075-1092, 2006.

Wen, S. and Rose, W. I.: Retrieval of sizes and total masses of particles in volcanic clouds using AVHRR bands 4 and 5, J. Geophys. Res., 99(D3), 5421-5431, 1994.

Westrich, H. R. and Gerlach, T. M.: Magmatic gas source for the stratospheric $\mathrm{SO}_{2}$ cloud from the 15 June 1991 eruption of Mount Pinatubo, Geology, 20(10), 867-870, doi:10.1130/00917613, 1992.

Wigley, T. M. L.: A combined mitigation/geoengineering approach to climate stabilization, Science, 314, 452-454, 2006.

Wu, M.-L.: A method for remote sensing the emissivity, fractional cloud cover and cloud top temperature of high-level, thin cirrus, J. Clim. Appl. Meteorol., 26(2), 225-233, 1987. 